\title{
Fall foliar sprays prevent boron-deficiency symptoms in grapes
} by L. Peter Christensen, Robert H. Beede
and William L. Peacock

Foliar spraying was found to be an effective method to rapidly increase boron levels in most vegetative and reproductive tissues in grapevines. The reduction of fruit-set deficiency symptoms with a pre-bloom or bloom spray was immediate but not complete. Foliar sprays applied during the previous fall were more effective in reducing such symptoms than pre-bloom or bloom sprays. This may be due to the earlier incorporation of boron in reproductive tissues, especially dormant buds. Grapevine foliage is also more tolerant to boron postharvest in the fall, when 1 pound per acre of actual boron can be safely applied. Spring and summer sprays of boron should be limited to 1/2 pound per acre per application to avoid phytotoxicity.

A fter zinc, boron is the second mostimportant micronutrient deficiency problem in California vineyards. Boron deficiencies are most common in the old flood plains and alluvial fans of the Stanislaus, Merced, San Joaquin, Kings and Kaweah rivers; the Sierra Nevada foothills; and North Coast sites with basaltic soils subject to high rainfall. Vineyard boron deficiencies are mostly associated with soils derived from basaltic and granitic parent material of the Sierra Nevada and North Coast ranges. Low boron is also associated with higher rainfall areas and soils irrigated with snowmelt water originating from the Sierra Nevada. In contrast, boron levels are typically higher and can even be toxic in soils originating from marine sedimentary material, such as in the Central Coast range.

Grapevine reproductive tissues are most sensitive to boron deficiency, which results in reduced fruit-set, small "shot berries" that are round to

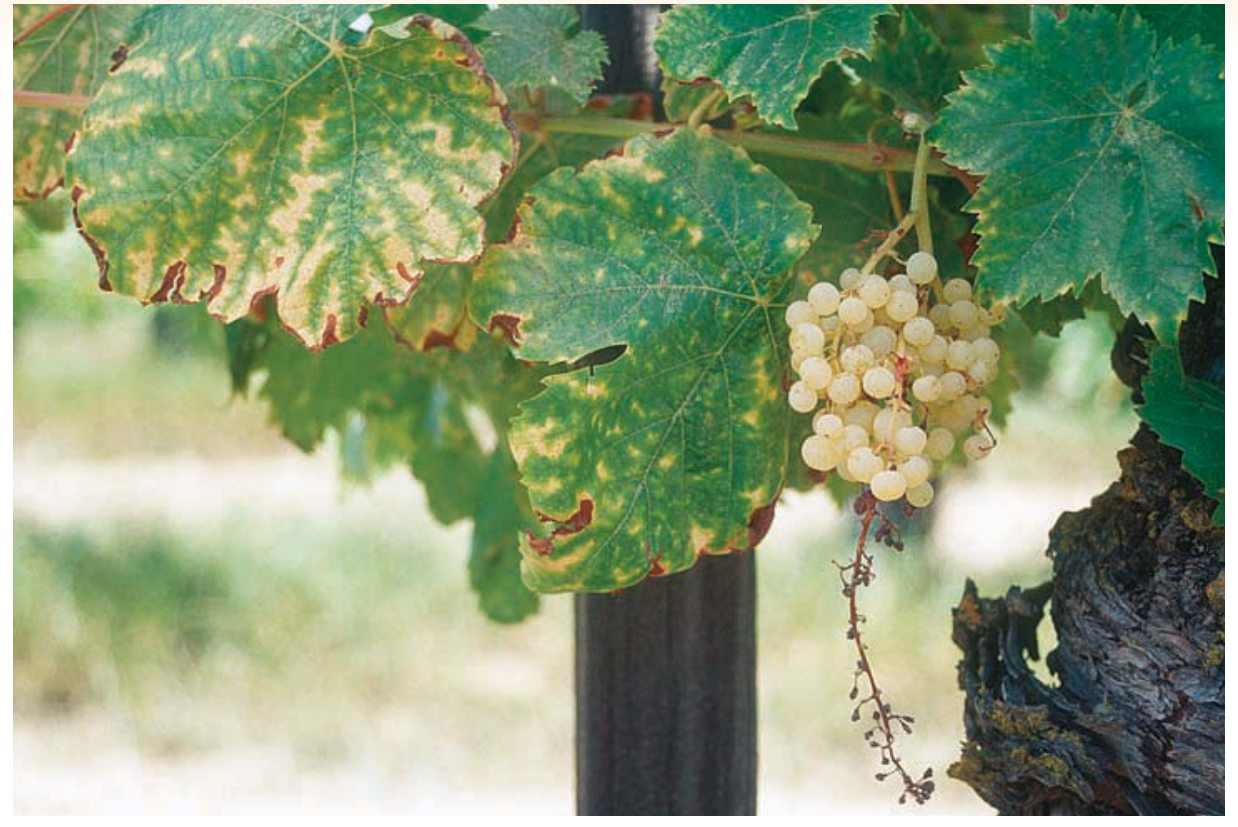

A boron-deficient Thompson Seedless cluster in the trial vineyard shows reduced fruit-set, the presence of numerous pumpkin-shaped "shot berries" and necrosis of some branching. Fewer than $10 \%$ of the berries are normal size and shape.

pumpkin-shaped, and flower and fruit cluster necrosis. Boron deficiency can have a drastic effect on fruit quality and yield, even when there are only mild-to-moderate foliar symptoms. At the same time, the over-application of boron can result in plant phytotoxicity. Phytotoxicity begins as a necrosis of the leaf margins that can cause a downward cupping of the young leaves. The necrosis intensifies and becomes more general as boron accumulates in older leaves.

Most commonly, grape growers have applied boron to the soil by hand or as a direct soil spray, sometimes in combination with an herbicide application (Christensen 1986; Christensen and Peacock 2000). However, such applications must be carefully timed to allow for winter rainfall or irrigation to move the boron into the root zone. Boron applications by foliar spray and drip irrigation are of increased interest for their convenience and the potential for faster vine response.

Foliar boron application has been studied in tree crops such as pears, prunes, cherries and almonds, and the application timing was found to influence fruit-set and development (Batjer and Thompson 1949; Callan et al. 1978; Hanson 1991b; Nyomora and Brown 1999). However, there is limited research on vine uptake and response to foliar boron and the potential for toxicity. We conducted several studies on the timing of boron foliar-spray applications in an eastern Fresno County vineyard with mild-to-moderate boron deficiency symptoms.

\section{Foliar sprays increase uptake}

The studies were conducted in 1998 and 1999 in an own-rooted, furrowirrigated 'Thompson Seedless' grape vineyard on Delhi loamy sand. The vineyard was irrigated with canal water and about 25\% supplementation from well water. The extremely low boron content of canal water can contribute to low boron availability in sandy vineyard soils.

A preliminary study was conducted in 1998 to determine the influence of foliar sprays on boron concentrations in vegetative and reproductive parts of the vine at bloom. Spray treatment was applied at $21 / 2$ weeks pre-bloom on May 6, 1998. The two comparative treat- 


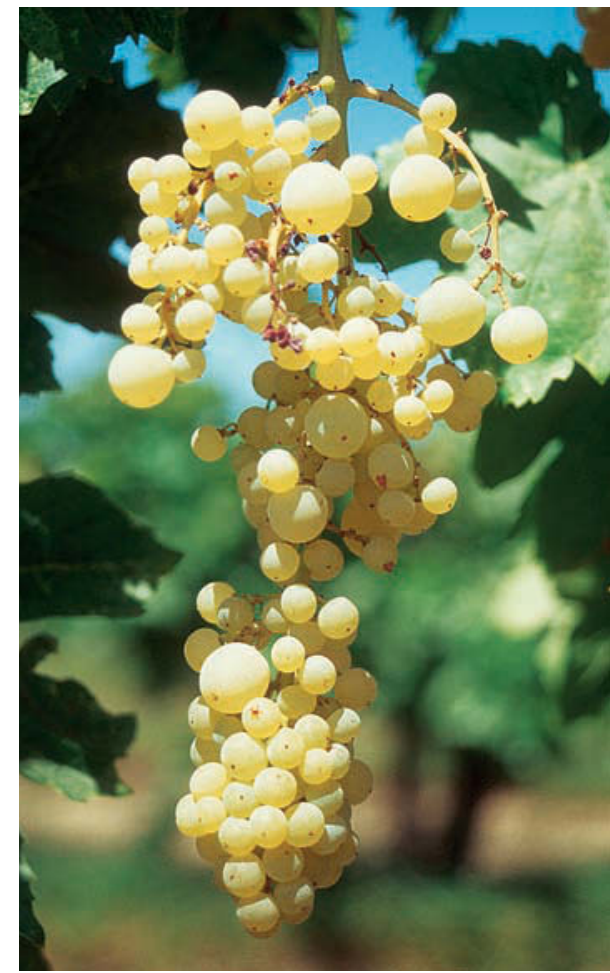

Boron foliar sprays applied in the fall were the most effective treatment to prevent, above, boron deficiency symptoms in grapes.

ments were an untreated control and a foliar boron spray at 1 pound per acre applied as Solubor (20.5\% boron) at 100 gallons per acre (gpa). The trial design was a randomized complete block with four-vine plots, replicated 10 times. Vine tissue samples were taken at bloom on May 23, 1998; triple-rinsed with distilled water and oven-dried; and analyzed for boron at the ANR Analytical Laboratory at UC Davis.

The comparative tissues were 30 opposite cluster petioles, 30 2-inch shoot tips and 15 flower clusters per plot. The flower clusters were separated into the cluster stem framework (rachis) and the individual unopened flowers (inflorescences). While the trial area was of low boron status, the presence of borondeficiency symptoms in fruit was not extensive enough to compare the treatments for visual evaluation or yield response.

Boron levels were significantly increased by the spray treatment in all of the sampled tissues (table 1), including tissues receiving the direct spray (petioles, rachis and inflorescence), as well as the new shoot-tip growth that was not yet present at the time of spraying. Care was taken to sample only actively growing shoot tips that had grown beyond the spray deposit. Representative shoot tips were marked with a black felt pen at the time of treatment, in order to measure subsequent new growth. Therefore, boron would have been translocated into the growing shoot tip from the sprayed tissues below. These results suggested that there is some phloem mobility of boron, and that foliar sprays have the potential to prevent boron deficiency of shoots in a timely manner during the growing season. (Phloem is the inner bark of a shoot that primarily conducts organic compounds.)

\section{Spray timing and type}

A follow-up study was conducted in the same vineyard during 1999, in an area observed in 1998 to be severely boron deficient. We compared the effects of boron timing and spray type (foliar vs. soil) on fruit-set and development as well as on vine tissue concentrations. There were five treatments: (1) control (untreated); (2) fall foliar, Oct. 19, 1998; (3) dormant soil berm spray, Feb. 8, 1999; (4) pre-bloom foliar, May 4, 1999; and (5) bloom foliar (50\% calyptrae [caps] off), May 20, 1999.

All treatments were applied at 1-pound boron per acre as $20.5 \%$ boron soluble product. The foliar sprays were applied at 150 gallons per acre, and the berm soil spray was applied at 30 gallons per acre (10 gallons per vineyard acre in a 4-footwide band along the vine row). The trial design was five-vine plots, replicated five times in a randomized block design.

Treatment effects on vine-tissue boron concentrations were determined with laboratory analysis. The following samples were collected: dormant canes (cane and bud tissues) in treatments 1 and 2 to determine boron uptake from the fall foliar spray, Feb. 26, 1998; early bloom (opposite cluster petioles, 2-inch shoot tips and entire flower clusters), May 17, 1999, in all treatments; and veraison (2-inch shoot tips), July 15, 1999, in all treatments.

Thirty samples of each tissue type were collected from each plot. The cane samples consisted of one-node sections (each cut at mid-internode). The buds were excised and analyzed separately. All tissue samples were triple-rinsed in distilled water, oven-dried and analyzed for boron at the ANR Analytical Laboratory at UC Davis.

Fruit response was determined by visually grading all individual clusters in each plot for the presence of boron deficiency symptoms on Aug. 15, 1999. Each cluster was scored as the percentage of the cluster showing combined symptoms of reduced fruit-set and the presence of the pumpkin-shaped shot berries characteristic of boron deficiency.

All of the data was subjected to ANOVA. When treatment effects were significant $(P \leq 0.05)$, treatment means were separated by Duncan's new multiple range test.

\section{Tissue boron increases}

The fall foliar treatment significantly increased boron levels in the dormant bud tissues, but the cane tissues were not affected (table 2). At bloom, the prebloom foliar treatment had the highest boron concentrations of all sampled tissues. The fall foliar treatment also increased bloom tissue boron levels, but not as much as the pre-bloom foliar treatment. The bloom treatment had not yet been sprayed at the time of tissue sampling and so was similar to the control. The dormant soil treatment did

\begin{tabular}{|c|c|c|c|c|}
\hline \multirow[b]{2}{*}{ Treatment } & \multicolumn{4}{|c|}{$\begin{array}{l}\text { TABLE 1. Effect of a pre-bloom boron (B) foliar spray on } \\
\text { eedless tissue boron levels at bloom, Kingsburg, Fresno County, } 1998\end{array}$} \\
\hline & Petioles & Rachis* & Inflorescencest & Shoot tips \\
\hline \multirow{3}{*}{$\begin{array}{l}\text { Control, no B } \\
\text { B foliar spray }\end{array}$} & \multicolumn{4}{|c|}{$\ldots \ldots \ldots \ldots \ldots \ldots \ldots \ldots p p$ pp dry $w t$. } \\
\hline & $24.6 b \neq$ & $19.2 b$ & $19.6 \mathrm{~b}$ & $26.4 b$ \\
\hline & $85.2 a$ & $103.4 a$ & $202.2 \mathrm{a}$ & $243.0 \mathrm{a}$ \\
\hline \multicolumn{5}{|c|}{ * Flower cluster stem structure only. } \\
\hline \multicolumn{5}{|c|}{ † Flower tissue only. } \\
\hline \multicolumn{5}{|c|}{$\begin{array}{l}\text { F Means followed by a different letter within columns are significantly different } \\
\text { according to Duncan's new multiple range test, } P \leq 0.05 \text {. }\end{array}$} \\
\hline
\end{tabular}


TABLE 2. Effect of boron soil and foliar spray treatment on Thompson Seedless tissue boron levels from dormancy to veraison, Kingsburg, Fresno County, 1999

\begin{tabular}{|c|c|c|c|c|c|c|}
\hline \multirow[b]{2}{*}{ Treatment } & \multicolumn{2}{|c|}{ Dormancy (Jan. 26) } & \multicolumn{3}{|c|}{ Bloom (May 17) } & \multirow{2}{*}{$\frac{\text { Veraison (July 15) }}{\text { Shoot tips }}$} \\
\hline & Canes & Buds & Petioles & Infl.* & Shoot tips & \\
\hline & \multicolumn{6}{|c|}{ ppm dry wt. } \\
\hline Control, no B & 10.6at & $20.2 b$ & $25.5 c$ & $14.8 c$ & $25.8 c$ & $27.6 \mathrm{~b}$ \\
\hline Fall, foliar & $10.0 a$ & $27.6 a$ & $32.3 b$ & $22.0 \mathrm{~b}$ & $32.8 \mathrm{~b}$ & $36.0 a$ \\
\hline Dormant, soil & - & - & $26.8 b c$ & $16.0 \mathrm{bc}$ & $28.2 a b c$ & $31.4 a b$ \\
\hline Pre-bloom, foliar & - & - & $90.2 a$ & $113.2 \mathrm{a}$ & $78.4 a$ & $35.6 a$ \\
\hline Bloom, foliar & - & - & $24.8 c$ & $14.6 \mathrm{c}$ & $28.8 b c$ & $36.6 a$ \\
\hline
\end{tabular}

not increase boron in the sampled tissues by bloom. At veraison, all of the foliar spray treatments (fall, pre-bloom and bloom) increased shoot-tip boron levels. The dormant soil treatment was intermediate among the treatments in shoot-tip boron concentration and was not different from either the control or the three foliar treatments. This 1999 study confirmed the 1998 pre-bloom spray treatment results by showing that boron concentrations increased in all of the sprayed tissues, as well as in new shoot tips thereafter.

\section{Foliar boron spraying can be used as a temporary or emergency treatment, or as a method of vineyard maintenance.}

Evidence of phytotoxicity after treatment was noted with the pre-bloom and bloom foliar sprays, but not with the fall foliar or the dormant soil berm sprays. Young, expanding leaves showed some necrosis and cupping at their margins. This demonstrated that spring and summer spray treatments should be used at a lower rate than the 1 pound of boron per acre used in our trial; one-half pound of boron per acre spray treatments have been shown to be safe at these times.

\section{Fall sprays best for fruit}

Boron deficiency in fruit was reported as incidence (clusters in which 5\% or more of the fruit had symptoms) and severity (mean percentage of deficiency symptoms appearing in all of the clusters). The incidence of boron deficiency in the control was 78\% (fig. 1A). Likewise, the fall foliar treatment had the lowest severity of boron-deficiency symptoms in fruit (3\%) (fig. 1B). The other boron treatments (dormant soil, pre-bloom foliar and bloom foliar) also reduced fruit symptom severity, but not as effectively as the fall foliar treatment.

Vine fruit response did not correspond directly with tissue boron levels. While fruit symptoms were reduced more effectively by the fall foliar than the pre-bloom foliar treatment, tissue boron levels were higher in the latter than in the former treatment. This may be due to the inability of the pre-bloom foliar spray to reverse some earlier effects of boron deficiency on primordial tissue in developing buds. Also, at pre-bloom, the calyptrae (caps) prevent the foliar spray from contacting the unexposed flower parts (anthers, stigma, style and ovaries). These calyptrae are shed at bloom, along with their spray deposits, finally exposing the flower parts to complete their pollination and fruit-set.

\section{Boron mobility}

Boron has long been recognized as being immobile or only slightly mobile in the phloem of many plant species (Brown et al. 2002). However, boron is highly mobile in the phloem of certain plants, including pome fruits, stone fruits and nut tree crops of Malus, Prunus and Pyrus spp., respectively (Brown and Hu 1998a, 1998b; Hanson 1991a). This boron mobility is due to the production of sugar alcohols, enabling the cotransport of boron-polyol complexes in the phloem (Brown et al. 1999). Such plants accumulate boron in their apical tissues and exhibit boron toxicity as shoot-tip dieback.

Tree crops that have responded well to foliar boron sprays at pre-bloom, bloom and / or fall include almonds (Nyomora et al. 2000), cherries (Hanson 1991b), pears (Batjer and Thompson 1949) and prunes (Callan et al. 1978). All of these trees have been demonstrated to

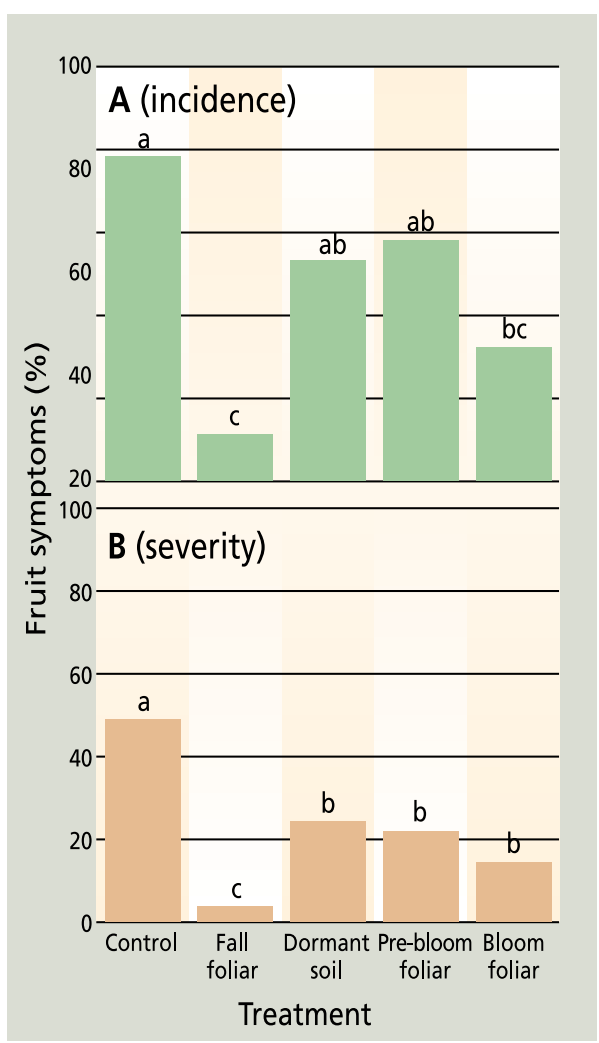

Fig. 1. Effects of boron soil and foliar spray treatment on $(A)$ incidence (mean \% clusters showing $>5 \%$ symptom expression) and (B) severity (mean \% of fruit showing deficiency in all clusters) in a Thompson Seedless grape vineyard, Kingsburg, 1999. Treatment means with different letters are significantly different according to Duncan's new multiple range test, $P \leq \mathbf{0 . 0 5}$.

be phloem-mobile for boron. Fall foliar boron sprays have sometimes shown superior improvements in both fruit-set and yields in prunes and almonds as compared to spring sprays (Callan et al. 1978; Nyomora and Brown 1999).

The mobility of boron in grapevine tissues is not well understood. Scott and Schrader (1947) found that boron concentrations in mature grape leaves declined when boron was absent from the root environment, suggesting remobilization of boron from leaves. Remobilization of boron is its movement from one organ to supply another organ or tissue in the plant. Brown and $\mathrm{Hu}$ (1998b) found native, wild grapevines (Vitis californica) to be intermediate in phloem boron mobility when compared to other woody plants. Nonmobile plants always accumulate boron in the edges of older leaves (Brown and $\mathrm{Hu}$ 1998a), a characteristic of the European grape Vitis vinifera (Christensen and Ayers 1974). Also, 


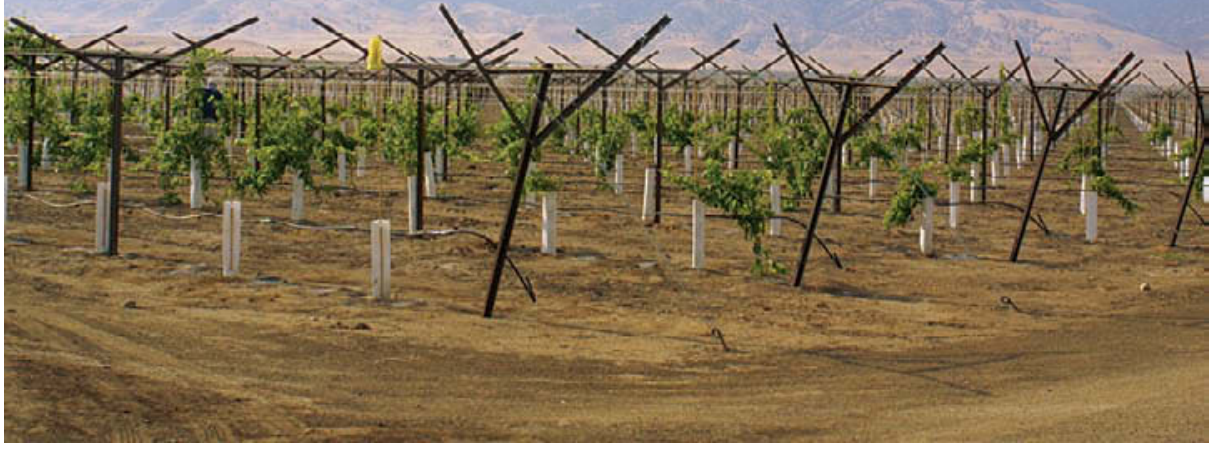

Boron deficiencies are common in the old flood plains and alluvial fans of California's Central Valley. Above, a newly planted table grape vineyard.

grapevines are susceptible to temporary boron deficiency of developing tissues during periods of drought, suggesting limited boron mobility.

Therefore, Vitis spp. do not appear to show the same characteristics of boron mobility and accumulation as the phloem-mobile tree crops of Malus, Prunus and Pyrus spp. In this study, some limitations in phloem boron mobility of grapevines may explain our finding that the pre-bloom boron spray was less effective at reducing fruit symptoms than the fall spray. Pre-bloom-applied boron may not have been sufficiently translocated into the flower parts by bloom to prevent some fruit symptom development. Conversely, fall-applied boron may have been incorporated into floral parts early enough to prevent most deficiency effects at bloom. The bloom spray tended to be intermediate between the pre-bloom and fall sprays in fruit response. At bloom, the calyptrae are shed, exposing the floral parts, including pollen, to a direct foliar spray. This direct contact with boron may have enhanced fruit-set as compared to the pre-bloom spray.

\section{Spray timing and rates}

Our results indicate that fall foliar treatment may be the best insurance against boron-deficient inflorescence tissues at bloom. While pre-bloom and bloom foliar treatments can also reduce boron-deficiency symptoms in fruit, growers should consider an earlier treatment in the fall because it may be more effective. Foliar spraying can also be used to correct vegetative boron-deficiency symptoms, as indicated by increased boron concentrations in shoot tips after spraying. The soil treatment in this study was only partially effective in correcting the boron deficiency. However, only 1 pound of actual boron was applied per acre, whereas 4 to 5 pounds boron per acre are normally recommended as an initial soil treatment under furrow irrigation. The 1-pound rate was used in all treatments in this trial to make a direct comparison of treatment method only.

Foliar boron spraying can be used as a temporary or emergency treatment, or as a method of vineyard maintenance. With annual treatment, there should ultimately be enough residual boron in the soil to provide for more constant uptake and long-term correction of the deficiency. Spring and summer applications of boron should not exceed 0.5 pound per acre for each spray to avoid phytotoxicity. Mild necrosis at the margins of immature leaves can occur at rates exceeding 0.6 to 0.8 pounds boron per acre. The annual recommended rate of 1-pound boron per acre can be safely achieved by applying two sprays of 0.5 pound each. However, vine foliage is more tolerant of boron after harvest in the fall, safely receiving up to 1 pound per acre in a single application.

Most soluble boron products are derived from sodium borates, resulting in well-buffered, alkaline solutions of $\mathrm{pH}$ 8.6 to 8.7 . If the boron is to be combined with a product that is susceptible to al- kaline hydrolysis, then it will be necessary to reduce the $\mathrm{pH}$ with an acidifier such as citric acid. (Always follow label directions.)

After initial foliar spray treatment, growers may wish to switch to another method of boron application for maintenance, such as fertigation with drip irrigation (Peacock and Christensen 2005). The choice of application method can be based on equipment availability and convenience while using the same fertilizer product. Growers should also routinely monitor boron treatments with leaf petiole or blade analysis, due to the narrow margin between boron deficiency and toxicity.

L.P. Christensen is Cooperative Extension Specialist, Emeritus, Department of Viticulture and Enology, UC Davis; R.H. Beede is Farm Advisor, UC Cooperative Extension, Kings County; and W.L. Peacock is Farm Advisor, UC Cooperative Extension, Tulare County.

\section{References}

Batjer LP, Thompson AH. 1949. Effect of boric acid sprays applied during bloom upon the set of pear fruits. Proc Amer Soc Hort Sci 53:141-2.

Brown PH, Bellaloui N, Wimmer MA, et al. 2002 Boron in plant biology. Plant Biol 4:205-23.

Brown PH, Hu H. 1998a. Boron mobility and consequent management in different crops. Better Crops with Plant Food 2:13-5.

Brown PH, Hu H. 1998b. Phloem boron mobility in diverse plant species. Bot Acta 111:331-5.

Brown PH, Hu H, Roberts WG. 1999. Occurrence of sugar alcohols determines boron toxicity symptom of ornamental species. J Amer Soc Hort Sci 124(4):347-52.

Callan NW, Thompson MM, Chaplin MH, et al 1978. Fruit-set of Italian prune following fall foliar and spring boron sprays. J Amer Soc Hort Sci 103:253-7.

Christensen LP. 1986. Boron application in vineyards. Cal Ag 40(3-4):17-8.

Christensen LP, Ayers RS. 1974. Boron and salinity in vineyards of the west side, Fresno County. Cal Ag 28(8):10-1.

Christensen LP, Peacock WL. 2000. Mineral nutrition and fertilization. In: Raisin Production Manual. UC ANR Pub 3393, ch. 14

Hanson EJ. 1991a. Movement of boron out of tree fruit leaves. HortScience 26:271-3.

Hanson EJ. 1991b. Sour cherries trees respond to foliar boron applications. HortScience 26:1142-5.

Nyomora AMS, Brown PH. 1999. Rate and time of boron application increase almond productivity and tissue boron concentration. HortScience 34(2):242-5.

Nyomora AMS, Brown PH, Pinney K, Polito VS. 2000 Foliar application of boron to almond trees affects pollen quality. J Amer Soc Hort Sci 125(2):265-70.

Peacock WL, Christensen LP. 2005. Drip irrigation can effectively apply boron to San Joaquin Valley vineyards. Cal Ag 59:188-91.

Scott LE, Schrader AL. 1947. Effect of alternating conditions of boron nutrition upon growth and boron content of grapevines in sand culture. Plant Physiol 22:526-37. 